\title{
COMPARISON OF THE GASIFICATION POTENTIAL OF RICE HUSK SAMPLES FROM BRAZIL AND THAILAND
}

\author{
E. VIRMOND ${ }^{1}$, Y. SOMRANG ${ }^{2}$, M. BOOT-HANDFORD ${ }^{3}$, C. C. DEAN ${ }^{3}$, N. H. FLORIN ${ }^{3}$, N. P. \\ M. PATERSON ${ }^{3}$, R. F. P. M. MOREIRA ${ }^{4}$, H. J. JOSÉ ${ }^{4}$, P. S. FENNELL ${ }^{3}$ \\ ${ }^{1}$ Universidade Federal de Santa Catarina, Campus Araranguá, Brasil \\ ${ }^{2}$ National Metal and Materials Technology Center (MTEC), Thailand \\ ${ }^{3}$ Imperial College London, Department of Chemical Engineering, England, United Kingdom \\ ${ }^{4}$ Universidade Federal de Santa Catarina, Departamento de Engenharia Química e Engenharia de \\ Alimentos, Campus Florianópolis, Brasil \\ E-mail para contato: elaine.virmond@ufsc.br
}

\begin{abstract}
RESUMO - This work aimed at comparing the gasification potential of rice husk samples from Brazil (CAZ1) and Thailand (CAZ2). The pyrolysis step was performed in two pyrolysis reactors under different conditions. The product yields were determined and related to the pyrolysis conditions applied. The biomass and rice husk chars were characterized and overall char combustion and gasification reactivities were measured by thermogravimetry in synthetic air and in $\mathrm{CO}_{2}$, respectively. The differences in samples properties play important roles in the thermochemical conversion steps. These differences may reflect local variations of the agricultural growing conditions, as noticed between the two rice husk samples studied, being the Thai rice husk char more reactive than the Brazilian one both in air and $\mathrm{CO}_{2}$ gasification.
\end{abstract}

\section{INTRODUÇÃO}

Rice husk is an important agroindustrial solid residue both in Brazil and Thailand. Many studies in the literature dealt with the relation between pyrolytic conditions with either char reactivity or char structure during biomass gasification (Pindoria et al, 1998; Mansaray and Ghaly, 1999; Mansaray et al, 1999; Adánez et al, 2001; Biagini et al, 2008; Asadullah et al, 2009). The parameters studied include heating rate, final temperature, pressure, residence time of volatiles and particle size and distribution (Guerrero et al., 2005; Cousins et al, 2006 a, b; Biagini et al., 2008). The char structure affects the subsequent oxidation step given that the pores size and distribution determines the accessibility of the reaction gas to the active sites (Bar-Ziv et al, 1998; Arenillas et al, 2002). Compared with most bituminous coals, biomass materials present significant amounts of alkali and alkaline earth metallic (AAEM) species (mainly $\mathrm{K}, \mathrm{Na}, \mathrm{Mg}$ and $\mathrm{Ca}$ ), which tend to volatilise during pyrolysis (and gasification/combustion), being of important consideration in all aspects of biomass thermochemical conversion. When retained in char during pyrolysis, are important catalysts for the gasification/combustion of char (Raveendran and Ganesh, 1998; Zolin et $a l, 2001)$, helping to reduce the gasification temperature and increase the overall process efficiency.

\section{MATERIAL AND METHODS}

\subsection{Biomass characterisation}


The Brazilian rice husk sample (CAZ1) was characterised as described below. The characterisation results for the rice husk sample from Thailand (CAZ2) have been provided by the researcher Yatika Somrang and only the results have been reported. CAZ1 and CAZ2 samples were ground and sieved to (106-150) $\mu \mathrm{m}$ sized particles and dried in a re-circulating air oven at $35^{\circ} \mathrm{C}$ for $16 \mathrm{~h}$, stored in small glass bottles in the fridge at approximately $6^{\circ} \mathrm{C}$ prior to pyrolysis experiments.

2.1.1 Proximate and ultimate analyses: Proximate analysis (moisture (M), volatile matter (VM), ash (A), fixed carbono (FC)) was carried out following DIN 51718 (DIN, 2002), DIN 51720 (DIN, 2001) and DIN 51719 (DIN, 1997), respectively. Ultimate analysis (C, H, N, S, O) was carried out according to the ASTM D3176 method (ASTM, 1997). The oxygen content was calculated by difference. Chloride was measured using selective ion electrodes (Cole-Parmer).

2.1.2 Heating Value: The Higher Heating Value (HHV) and the Lower Heating Value (LHV) were determined by applying the methods ASTM D5865 (ASTM, 2004) and DIN 51900 parts 1 and 3 (DIN, 2000; DIN, 2005) to samples previously dried. The HHV was determined in a calorimeter and the LHV was calculated using the Dulong equation (1), with HHV and LHV in MJ. $\mathrm{kg}^{-1}, \mathrm{H}$ is the mass fraction of hydrogen and $\mathrm{M}$ the moisture content of the sample:

$$
L H V=H H V-2.43 \cdot(9 \cdot H+M)
$$

\subsection{Biomass pyrolysis}

Pyrolysis experiments were carried out in: (1) a horizontal tube furnace (TF) and (2) a hot-rod reactor (HRR), which were described by Virmond (2011). The operating conditions were presented in Table 1 . The residence time was previously tested and $900 \mathrm{~s}$ was the minimun necessary to promote complete devolatilisation of the sample at the temperatures evaluated.

Table 1 - Conditions applied to the pyrolysis experiments with CAZ1 and CAZ2

\begin{tabular}{|c|c|c|c|c|c|c|c|}
\hline & $\begin{array}{c}\mathrm{PS}^{\mathrm{a}} \\
{[\mu \mathrm{m}]}\end{array}$ & $\begin{array}{c}\mathrm{T}^{\mathrm{b}} \\
{\left[{ }^{\circ} \mathrm{C}\right]}\end{array}$ & $\begin{array}{c}\mathrm{HR}^{\mathrm{c}} \\
{\left[{ }^{\circ} \mathrm{C} \cdot \mathrm{s}^{-1}\right]}\end{array}$ & $\begin{array}{l}\mathrm{t}_{\mathrm{r}}{ }^{\mathrm{d}} \\
{[\mathrm{s}]}\end{array}$ & $\mathrm{Gas}^{\mathrm{e}}$ & $\begin{array}{c}\mathrm{p}^{\mathrm{f}} \\
{[\mathrm{bar}]}\end{array}$ & $\begin{array}{c}\mathrm{v}_{\mathrm{s}}^{\mathrm{g}} \\
{\left[\mathrm{m} \cdot \mathrm{s}^{-1}\right]}\end{array}$ \\
\hline \multicolumn{8}{|c|}{ Tube furnace } \\
\hline CAZ1 & $(106-150)$ & $350,500,700,850$ & 0.8 & 900 & $\mathrm{~N}_{2}$ & 1.0 & 0.1 \\
\hline CAZ2 & $(106-150)$ & $350,500,700,850$ & 0.8 & 900 & $\mathrm{~N}_{2}$ & 1.0 & 0.1 \\
\hline \multicolumn{8}{|c|}{ Hot-rod reactor } \\
\hline CAZ1 & $(106-150)$ & 500 & 1 & 900 & $\mathrm{He}$ & 2.2 & 0.1 \\
\hline CAZ2 & $(106-150)$ & 500 & 1 & 900 & $\mathrm{He}$ & 2.2 & 0.1 \\
\hline
\end{tabular}

reactor; ${ }^{\mathrm{g}}$ Superficial velocity of the carrier gas.

2.1.1 Pyrolysis in the TF: A tube furnace (STF Model 16/180, Carbolite) was used. A quartz tube of $10 \mathrm{~mm}$ internal diameter, $12 \mathrm{~mm}$ outer diameter and $113 \mathrm{~cm}$ long was fitted into the ceramic tube of the furnace to serve as a support for the sample holder assembly and to limit the pyrolysis environment for smaller mass samples. Sample mass between 0.085 and $0.200 \mathrm{mg}$ of pre-dried biomass were reacted. Each test was repeated at least twice (the repeatability was tested for one sample/condition in five runs at the same conditions). The spread of the data has been estimated by calculating the standard deviations from the results of multiple tests.

2.1.2 Pyrolysis in the HRR: The description of the version of the reactor developed by the 
Combustion, Gasification and $\mathrm{CO}_{2}$ Capture group from the Imperial College London and used in the present study as well as of the reactor operation was given by Dabai et al. (2010). The HRR runs have been performed with only the first of two stages, which was connected directly to the tar trap. A flow of inert gas $(\mathrm{He})$ was used to sweep the released volatiles into the tar trap placed in a liquid nitrogen bath so that the volatiles released from the reactor could be condensed and trapped. Each test was repeated 1-2 times. The spread of the data has been estimated by calculating the standard deviations from the results of multiple tests. Gas chromatography device (model Clarus 500, Perkin Elmer, FID/TCD) has been used to characterise and quantify the gas components condensed in the tar trap. A packed Alumina F-1 60/80 column was used for analysis of hydrocarbons and a packed Hayesep N60/80 mesh column for $\mathrm{CO}_{2}$ determinations. $\mathrm{CH}_{4}$ and $\mathrm{CO}$ could not be efficiently collected in the tar trap. Two online ADC analysers based on infrared detection were used to measure the amount (\%) of these gas components. The analysers were previously calibrated with a certified gas mixture (supplied by BOC gases).

\subsection{Characterisation of the pyrolysis char}

2.3.1 Proximate and elemental composition: The ultimate analysis (CHN) of CAZ1 and CAZ2 char samples produced in the TF at $500{ }^{\circ} \mathrm{C}$ and $850{ }^{\circ} \mathrm{C}$, and in the $\mathrm{HRR}$ at $500{ }^{\circ} \mathrm{C}$ was carried out according to the ASTM D3176 method (ASTM, 1997). The oxygen content was calculated by difference. The contents of moisture, volatiles and fixed carbon were obtained from the TGA experiments performed for measuring the combustion reactivity in a instrument TGA Q 500 (TA Instruments Inc.), such as described in the following section.

2.3.2 Char combustion reactivity in synthetic air: The methodology used by Cousins et al. (2006 a, b) has been applied to CAZ1 and CAZ2 char samples produced in the TF and in the HRR at $500{ }^{\circ} \mathrm{C}$. A standard isothermal TGA test using a TGA Q 500 (TA Instruments Inc.) was applied to samples of (1.5-3.0) mg. Analysis steps: (1) equilibrium at $50{ }^{\circ} \mathrm{C}$ under $\mathrm{N}_{2}$, isotherm for $1 \mathrm{~min}$; (2) heating at $40{ }^{\circ} \mathrm{C} \cdot \mathrm{min}^{-1}$ to $110^{\circ} \mathrm{C}$ under $\mathrm{N}_{2}$ at $40 \mathrm{~mL} \cdot \mathrm{min}^{-1}$ and isotherm for $10 \mathrm{~min}$ (moisture content); (3) heating at $40{ }^{\circ} \mathrm{C} \cdot \mathrm{min}^{-1}$ to $500{ }^{\circ} \mathrm{C}$ and weight stabilisation (VM content); (4) swicht from $\mathrm{N}_{2}$ to air; (5) hold under previous conditions until at least $50 \%$ of the sample had reacted; (6) heating at $20^{\circ} \mathrm{C} \cdot \mathrm{min}^{-1}$ to $850{ }^{\circ} \mathrm{C}$ to combust the remaining sample and isotherm for additional $5 \mathrm{~min}$ (ash content). Weight losses were recorded continuously and the char conversion $(X)$ and char reactivity $(r)$ were calculated by applying the equations (2) and (3).

$$
\begin{aligned}
& X=\left(\frac{m_{0}-m}{m_{0}}\right) \\
& r=-\frac{1}{m_{0}}\left(\frac{d m}{d t}\right)
\end{aligned}
$$

Where $r$ is the reactivity (given in $\mathrm{mg} \cdot \mathrm{mg}^{-1} \cdot \mathrm{min}^{-1}$ ), $m_{0}$ is the initial weight of the char sample (daf basis) for the combustion step, $m$ is the instantaneous sample mass (daf basis) and ( $d m / d t$ ) is the rate of weight loss. Only single determinations have been reported, being the repeatability of $r$ determination $\pm 9 \%$ of the value quoted.

2.3.3 Char gasification reactivity in $\mathrm{CO}_{2}$ : The experiments were carried out in a thermogravimetric analyser (model DTG 60, Shimadzu) in $\mathrm{CO}_{2}$ atmosphere at (850-950) ${ }^{\circ} \mathrm{C}$ with 
CAZ1 and CAZ2 ((22-27) mg, (106-150) $\mu \mathrm{m}$, moisture content of $8.71 \mathrm{wt} \%$ and $9.00 \mathrm{wt} \%$, respectively). The pyrolysis step was performed in the proper thermogravimetric analyser as a step previous to char gasification. Analysis steps: (1) purge with $\mathrm{N}_{2}$ at $100 \mathrm{~mL} \cdot \mathrm{min}^{-1}$ and $35^{\circ} \mathrm{C}$ for 60 min; (2) heating at $50{ }^{\circ} \mathrm{C} \cdot \mathrm{min}^{-1}$ to $110{ }^{\circ} \mathrm{C}$ under $\mathrm{N}_{2}$ at $100 \mathrm{~mL} \cdot \mathrm{min}^{-1}$ and isotherm for $5 \mathrm{~min}$; (3) pyrolysis step: heating at $50{ }^{\circ} \mathrm{C} \cdot \mathrm{min}^{-1}$ to $850{ }^{\circ} \mathrm{C}$ under $\mathrm{N}_{2}$ at $100 \mathrm{~mL} \cdot \mathrm{min}^{-1}$ and isotherm for $15 \mathrm{~min}$; (4) heating at $50{ }^{\circ} \mathrm{C} \cdot \mathrm{min}^{-1}$ up to the reaction temperature $\left(837^{\circ} \mathrm{C}, 888{ }^{\circ} \mathrm{C}, 912{ }^{\circ} \mathrm{C}\right.$ or $\left.936{ }^{\circ} \mathrm{C}\right)$ under $\mathrm{N}_{2}$ at $100 \mathrm{~mL} \cdot \mathrm{min}^{-1}$; (5) gasification step: swicht from $\mathrm{N}_{2}$ to $\mathrm{CO}_{2}$ at $100 \mathrm{~mL} \cdot \mathrm{min}^{-1}$, with isotherm for $120 \mathrm{~min}$. The comparison of the char samples reactivity in $\mathrm{CO}_{2}$ (both prepared at $850{ }^{\circ} \mathrm{C}$ ) was only made for the gasification temperature of $837^{\circ} \mathrm{C}$ in order to check whether the difference observed for the char reactivity in synthetic air at $500{ }^{\circ} \mathrm{C}$ (chars produced at pyrolysis temperature of $500{ }^{\circ} \mathrm{C}$ ) also occurred in these conditions. The data aquisition was initiated after the purge step was complete. In order to obtain preliminary information about the $\mathrm{CO}_{2}$ gasification potential of CAZ1 char, it has been analysed in the same conditions previously described at three additional gasification temperatures: $888^{\circ} \mathrm{C}, 912{ }^{\circ} \mathrm{C}$ and $936^{\circ} \mathrm{C}$. The degree of carbon conversion $(X)$ and the reactivity $\left(r_{c}\right)$ in terms of carbon content for gasification with $\mathrm{CO}_{2}$ was determined by applying equations (2) and (3) to the data obtained from TGA runs, being $m_{0}$ the initial mass of carbon (determined by elemental analysis) in the char sample, $m$ the instantaneous mass of carbon in the char sample, and $d m / d t$ the rate of carbon mass loss. The activation energy $\left(E_{a}\right)$ in $\mathrm{CO}_{2}$ gasification was calculated by plotting $\ln r_{\text {cmax }}$ as a function of $(1 / T)$ for the Arrhenius equation (4):

$$
r_{\text {cmáx }}=k_{0} \cdot \exp \left(\frac{-E_{a}}{R T}\right)
$$

Where $r_{c \max }$ is the maximum reactivity $\left(\mathrm{mg} \cdot \mathrm{mg}^{-1} \cdot \mathrm{min}^{-1}\right)$ measured during the gasification of the carbon present in the char sample in a given reaction temperature, $k_{0}$ is the pre-exponential factor $\left(\mathrm{min}^{-1}\right), E_{a}$ is the activation energy $\left(\mathrm{J} \cdot \mathrm{mol}^{-1}\right), R$ is the gas constant $\left(8,314 \mathrm{~J} \cdot \mathrm{mol}^{-1} \cdot \mathrm{K}^{-1}\right)$ and $T$ the absolute temperature $(\mathrm{K})$. This method is applied to the results obtained under the chemically controlled regime. The transition from the chemical to the diffusion-controlled regime can be detected from the change in the slope on the Arrhenius plot.

2.3.4 SEM/EDS analysis: The char samples produced from CAZ1 and CAZ2 in the TF and in the HRR at $500{ }^{\circ} \mathrm{C}$ were analised using a Scanning Electron Microscope (SEM) (model TM-1000, Hitachi) equipped with an Energy Dispersive X-ray Spectrometer (EDS) (model SwiftED-TM, Hitachi). The char samples produced from CAZ1 and CAZ2 in the TF at $850{ }^{\circ} \mathrm{C}$ were analised using a Scanning Electron Microscope (SEM) (model EDAX DX-4/EDS, Phillips).

2.3.5 Trace elements analysis: $\mathrm{Cu}, \mathrm{Mg}, \mathrm{Mn}, \mathrm{Be}, \mathrm{Co}, \mathrm{Mo}, \mathrm{V}, \mathrm{Cr}, \mathrm{As}, \mathrm{Cd}, \mathrm{Ni}$ and $\mathrm{Zn}$ in the char samples have been quantified by Inductively Coupled Plasma - Optical Emission Spectrometry (ICP-OES) after digestion by nitric acid in a closed bomb within a microwave oven in order to investigate possible catalytic effects on the char reactivity. Details of trace element quantification have been presented elsewhere (Richaud et al., 1998; Richaud et al., 2000; George et al., 2008).

\section{RESULTS AND DISCUSSION}

\subsection{Biomass properties}


Table 2 - Biomass properties

\begin{tabular}{|c|c|c|}
\hline Biomass & CAZ1 & CAZ2 \\
\hline \multicolumn{3}{|c|}{ Proximate analysis } \\
\hline $\mathrm{A}^{\mathrm{a}}\left(\%, \mathrm{db}^{\mathrm{b}}\right)$ & 13.43 & 16.80 \\
\hline $\mathrm{VM}^{\mathrm{c}}\left(\%, \mathrm{daf}^{\mathrm{d}}\right)$ & 76.19 & 77.54 \\
\hline $\mathrm{FC}^{\mathrm{e}}(\%, \mathrm{daf})$ & 23.81 & 22.46 \\
\hline $\mathrm{M}^{\mathrm{f}}\left(\%, a \mathrm{r}^{\mathrm{g}}\right)$ & 6.89 & 10.10 \\
\hline \multicolumn{3}{|c|}{ Ultimate analysis } \\
\hline $\mathrm{C}(\%, \mathrm{daf})$ & 43.14 & 46.98 \\
\hline $\mathrm{H}(\%, \mathrm{daf})$ & 5.57 & 5.86 \\
\hline $\mathrm{N}(\%$, daf $)$ & 0.36 & 0.80 \\
\hline $\mathrm{S}(\%, \mathrm{daf})$ & $<0.01^{\mathrm{h}}$ & 0.05 \\
\hline $\mathrm{O}^{\mathrm{i}}(\%, \mathrm{daf})$ & 50.91 & 45.95 \\
\hline $\mathrm{Cl}(\%$, daf $)$ & 0.02 & 0.36 \\
\hline \multicolumn{3}{|c|}{ Heating value $\left({\left.\mathrm{MJ} . \mathrm{kg}^{-1}\right)}^{-1}\right.$} \\
\hline $\mathrm{HHV}^{\mathrm{j}}$ (daf) & 19.06 & 19.93 \\
\hline $\mathrm{LHV}^{\mathrm{k}}$ (daf) & 17.59 & 17.79 \\
\hline
\end{tabular}

\subsection{Pyrolysis experiments}

The pyrolysis experiments at $500{ }^{\circ} \mathrm{C}$ in the TF presented the best results in terms of low char yield comparatively to the other temperatures tested. CAZ2 produced a relatively low amount of tar and a relatively high amount of volatiles in the HRR, which implies that it may be the most promising feed of the suite tested as a gasification feedstock. Venderbosch and Prins (2010) discussed the effects of ash properties on biomass pyrolysis, suggesting that high ash content favours charring reactions, which increases char yield. CAZ1 and CAZ2 contained $13.43 \mathrm{wt} \%$ and 16.80 $\mathrm{w} \%(\mathrm{db})$ ash, respectively. The order of the amounts of ash corresponds to the amounts of solid residue (char and ash) produced. Hence it appears that the larger the amount of ash, the larger the amount of char produced. However, as the ash content increases, the $\mathrm{C}$ content falls so that the quality of the char (in terms of energy content) falls. Therefore, although a high ash content sample produces more char, the quality of the char produced may not be very good. The total amount of recovered products (tar and chars) was higher than $61 \%$ of the original biomass for the two rice husk samples. Comparison with the char yield from the tubular furnace indicates that there was significantly more char remaining when the material was studied in the HRR. This may be due to the higher pressure required in the HRR. The amounts of $\mathrm{CH}_{4}, \mathrm{CO}$ and $\mathrm{CO}_{2}$ released by CAZ1 $\left(0.2 \%, 1.4 \%, 4.0 \%\right.$, respectively) in the HRR at $500{ }^{\circ} \mathrm{C}$ were slightly higher than the amounts released by CAZ2 $(0.1 \%, 1.1 \%, 3.5 \%$, respectively).

\subsection{Pyrolysis char properties}

3.1.1 Proximate and ultimate composition: Table 3 presents the results for the samples prepared in the TF and HRR. C, H, N were determined only for the runs at $500{ }^{\circ} \mathrm{C}$ and $850{ }^{\circ} \mathrm{C}$.

3.1.2 Char combustion reactivity in synthetic air: The maximum combustion reactivity $\left(r_{\max }\right)$ at $500{ }^{\circ} \mathrm{C}$ was higher $\left(0.312 \mathrm{mg} \cdot \mathrm{mg}^{-1} \cdot \mathrm{min}^{-1}\right.$ for CAZ1 and $0.760 \mathrm{mg} \cdot \mathrm{mg}^{-1} \cdot \mathrm{min}^{-1}$ for CAZ2) for the chars produced at $500{ }^{\circ} \mathrm{C}$ in the TF compared to the three other pyrolysis temperatures. 
Table 3 - Char properties

\begin{tabular}{|c|c|c|c|c|c|c|c|c|}
\hline Biomass & $\mathrm{T}^{\mathrm{a}}$ & $\mathbf{M}^{\mathrm{b}}$ & $\mathrm{VM}^{\mathrm{c}}$ & $A^{d}$ & $\mathrm{FC}^{\mathrm{e}}$ & $\mathrm{C}$ & $\mathrm{H}$ & $\mathrm{N}$ \\
\hline & $\left({ }^{\circ} \mathrm{C}\right)$ & $(\mathrm{wt} \%, \mathrm{db})$ & $(\mathrm{wt} \%, \mathrm{db})$ & $(\mathrm{wt} \%, \mathrm{db})$ & $(\mathrm{wt} \%, \mathrm{db})$ & $(\mathrm{wt} \%, \mathrm{db})$ & $(\mathrm{wt} \%, \mathrm{db})$ & (wt\%, db) \\
\hline \multicolumn{9}{|c|}{ Tube furnace } \\
\hline CAZ1 & 350 & 0.66 & 26.28 & 26.98 & 46.74 & n.d. ${ }^{f}$ & n.d. & n.d. \\
\hline CAZ1 & 500 & 2.15 & 6.48 & 40.15 & 53.37 & $43.48 \pm 0.21$ & $2.58 \pm 0.21$ & $0.83 \pm 0.07$ \\
\hline CAZ1 & 700 & 0.32 & 1.89 & 46.00 & 52.11 & n.d. & n.d. & n.d. \\
\hline CAZ1 & 850 & 1.13 & 5.77 & 46.79 & 47.44 & $47.35 \pm 0.21$ & $1.72 \pm 0.21$ & $0.80 \pm 0.07$ \\
\hline CAZ2 & 350 & 1.16 & 22.64 & 31.47 & 45.99 & n.d. & n.d. & n.d. \\
\hline CAZ2 & 500 & 1.22 & 6.85 & 42.54 & 50.62 & $45.03 \pm 0.21$ & $2.57 \pm 0.21$ & $0.81 \pm 0.07$ \\
\hline CAZ2 & 700 & 1.74 & 2.92 & 46.57 & 50.52 & n.d. & n.d. & n.d. \\
\hline CAZ2 & 850 & 1.05 & 2.76 & 47.84 & 49.40 & $42.05 \pm 0.21$ & $1.45 \pm 0.21$ & $0.50 \pm 0.07$ \\
\hline \multicolumn{9}{|c|}{ Hot-rod reactor } \\
\hline CAZ1 & 500 & 3.29 & 8.78 & 35.53 & 55.69 & $49.48 \pm 0.21$ & $2.85 \pm 0.21$ & $1.15 \pm 0.07$ \\
\hline CAZ2 & 500 & 3.07 & 9.60 & 33.46 & 56.94 & $35.58 \pm 0.21$ & $2.19 \pm 0.21$ & $0.55 \pm 0.07$ \\
\hline
\end{tabular}

The reason for the decrease in char reactivity with the increase in pyrolysis temperature may be due to the increased structural ordering of the carbon matrix, which has the effect of reducing the concentration of reaction sites, such as suggested by Kumar and Gupta (1994). The $r_{\max }$ of CAZ2 was 2-5 times higher than the value found for CAZ1 char at all pyrolysis temperatures in the TF. Comparing CAZ1 and CAZ2 chars produced in the HRR at the same pyrolysis conditions, the $r_{\max }$ was also achieved for the Thai rice husk char, being almost two times higher $\left(0.518 \mathrm{mg} \cdot \mathrm{mg}^{-1} \cdot \mathrm{min}^{-1}\right)$ than the value found for CAZ1 char $\left(0.315 \mathrm{mg} \cdot \mathrm{mg}^{-1} \cdot \mathrm{min}^{-1}\right)$. Comparing the two reactors, the $r_{\max }$ of CAZ1 char at $500{ }^{\circ} \mathrm{C}$ was similar $\left(0.312 \mathrm{mg} \cdot \mathrm{mg}^{-1} \cdot \mathrm{min}^{-1}\right.$ for TF, and $0.315 \mathrm{mg} \cdot \mathrm{mg}^{-1} \cdot \mathrm{min}^{-1}$ for HRR). For CAZ2, on the other hand, the $r_{\max }$ of the char produced in the TF was $46.7 \%$ higher compared to the one produced in the HRR. According to Ollero et al. (2003) and Cetin et al. (2004), this can be attributed, in part, to the higher pressure applied during pyrolysis in the HRR (2.2 bar).

3.1.3 Char gasification reactivity in $\mathrm{CO}_{2}$ : The maximum gasification reactivity $\left(r_{c \max }\right)$ of CAZ2 char $\left(0.013 \mathrm{mg} \cdot \mathrm{mg}^{-1} \cdot \mathrm{min}^{-1}\right)$ was slightly higher than CAZ1 char $\left(0.008 \mathrm{mg} \cdot \mathrm{mg}^{-1} \cdot \mathrm{min}^{-1}\right)$, thus confirming the trend observed for reactiviy in air at $500{ }^{\circ} \mathrm{C}$. Besides gasification at $837{ }^{\circ} \mathrm{C}$, three other gasification temperatures were applied to CAZ1 char: $888{ }^{\circ} \mathrm{C}, 912{ }^{\circ} \mathrm{C}, 936{ }^{\circ} \mathrm{C}$. The total mass loss percentage of approximately $76 \mathrm{wt} \%$ was achieved in the pyrolysis step, which corresponds to the VM of CAZ1. The higher conversion was reached at $912{ }^{\circ} \mathrm{C}\left(X_{c}=0.57\right)$, followed by $888{ }^{\circ} \mathrm{C}$ $\left(X_{c}=0.54\right), 936{ }^{\circ} \mathrm{C}\left(X_{c}=0.52\right)$ and $837{ }^{\circ} \mathrm{C}\left(X_{c}=0.47\right)$. However, the reaction rate was higher at 936 ${ }^{\circ} \mathrm{C}$, being complete in approx. $50 \mathrm{~min}$. As expected, the $r_{c \max }$ for CAZ1 were essentially dependent on the final heat treatment temperature due to the significant improvement in internal surface area during gasification and/or the catalysis of mineral impurities which become more effective at relatively high temperatures, with higher values occurring at the higher temperature applied (936 $\left.{ }^{\circ} \mathrm{C}\right)$. It is known that the rate of gasification depends on the accessibility of the reactant gas to the internal surface of porous char where active sites reside. The experimental data was satisfactorily represented by the proposed equations, thus indicating that the reaction kinetics at the temperatures studied were in the chemical reaction control region. $E_{a}$ was equal to $72.91 \mathrm{~kJ} . \mathrm{mol}^{-1}$, value which is in the range found in the literature (70-220 $\mathrm{kJ}^{-\mathrm{mol}^{-1}}$ ) (Ollero et al., 2003; Fermoso et al., 2009; Link et al., 2010). The $k_{0}$ obtained was $24.32 \mathrm{~min}^{-1}$.

3.1.4 Trace elements and SEM/EDS analyses: CAZ1 chars (TF and HRR) contained 
particularly high $\mathrm{Zn}$ and Ni contents, while the CAZ2 chars (higher values for the combustion reactivity), presented higher concentrations of $\mathrm{Cu}$, probably reflecting local variations of the agricultural growing conditions. Elemental $\mathrm{Cu}$ can act as catalyst for clean gasification, either in nitrogen (to yield predominantly $\mathrm{CO}, \mathrm{CO}_{2}$ and hydrocarbons) or in an oxidizing gas. However, alkali and alkaline earth metals such as $\mathrm{Na}$ and $\mathrm{K}$, especially $\mathrm{Ca}$, have known catalytic effect on heterogeneous reactions which take place during biomass pyrolysis and gasification processes (Di Blasi et al., 1999). These were found in chars produced in the TF at $500{ }^{\circ} \mathrm{C}$. K was present in higher concentration in CAZ2 char $(35.80 \mathrm{wt} \%), 45 \%$ higher compared to CAZ1 $(19.55 \mathrm{wt} \%)$, probably responding for the higher CAZ2 reactivity. When CAZ1 and CAZ2 were pyrolysed at $850{ }^{\circ} \mathrm{C}$, the $\mathrm{K}$ content decreased $(5.51 \mathrm{wt} \%$ and $5.54 \mathrm{wt} \%$, respectively), what suggests that $\mathrm{K}$ has volatilised during pyrolysis at $850^{\circ} \mathrm{C}$, reflecting in slightly diferent values for the maximum gasification reactivity.

\section{CONCLUSION}

The gasification potential of both rice husk samples was verified. The influence of biomass properties and pyrolysis conditions on the char reactivity in both synthetic air and $\mathrm{CO}_{2}$ indicates that research on pyrolysis technology selection, improvement and optimisation aiming at obtaining products with the required characteristics for gasification has to be extended.

\section{REFERÊNCIAS}

ADÁNEZ, J.; DE DIEGO, L.F.; GARCÍA-LABIANO, F.; ABAD, A.; ABANADES, J.C. Determination of biomass char combustion reactivities for FBC applications by a combined method. Ind. Eng. Chem. Res., v. 40, p. 43174323, 2001.

ARENILLAS, A.; RUBIERA, F.; PARRA, J.B.; PIS, J.J. Influence of char structure on reactivity and nitric oxide emissions. Fuel Processing Technology, v. 77-78, p. 103-109, 2002.

ASADULLAH, M.; ZHANG, S.; MIN, Z.; YIMSIRI, P.; LI, C-Z. Importance of biomass particle size in structural evolution and reactivity of char in steam gasification. Ind. Eng. Chem. Res., v. 48, p. 9858-9863, 2009.

ASTM D3176, Standard practice for ultimate analysis of coal and coke, September 29, 1989 (reapproved 1997).

ASTM D5865, Standard test method for gross calorific value of coal and coke, April 1, 2004.

BAR-ZIV, E.; KANTOROVICH, I.I. Role of porous structure in char oxidation. Applied Thermal Engineering, v. 18, p. 991-1003, 1998.

BIAGINI, E.; FANTEI, A.; TOGNOTTI, L. Effect of the heating rate on the devolatilization of biomass residues. Thermochimica Acta, v. 472, p. 55-63, 2008.

CETIN, E.; MOGHTADERI, B.; GUPTA, R.; WALL, T.F. Influence of pyrolysis conditions on the structure and gasification reactivity of biomass chars. Fuel, v. 83, p. 2139-2150, 2004.

COUSINS, A.; PATERSON, N.; DUGWELL, D.R.; KANDIYOTI, R. An investigation of the reactivity of chars formed in fluidized-bed gasifiers: equipment development and initial tests. Energy \& Fuels, 20, p. 699-704, 2006 a.

COUSINS, A.; PATERSON, N.; DUGWELL, D.R.; KANDIYOTI, R. An investigation of the reactivity of chars formed in fluidized-bed gasifiers: the effect of reaction conditions and particle size on coal char reactivity. Energy \& Fuels, v. 20, p. 2489-2497, 2006 b.

DABAI, F.; PATERSON, N.; MILLAN, M.; FENNELL, P.S.; KANDIYOTI, R. Tar formation and destruction in a fixed-bed reactor simulating downdraft gasification: equipment development and characterization of tar-cracking products. Energy Fuels, v. 24, p. 4560-4570, 2010.

DI BLASI, C.; SIGNORELLI, G.; PORTORICCO, G. Countercurrent fixed-bed gasification of biomass at laboratory 
scale. Ind. Eng. Chem. Research, v. 38, p. 2571-2581, 1999.

DIN 51718 - Testing of solid fuels e determination of the water content and the moisture of analysis sample, June 1, 2002.

DIN 51719 - Testing of solid fuels e solid mineral fuels e determination of ash content, July 1, 1997.

DIN 51720 - Testing of solid fuels e determination of volatile matter content, March 1, 2001.

DIN 51900-1 - Determining the gross calorific value of solid and liquid fuels using the bomb calorimeter, and calculation of net calorific value e part 1: general information, 2000.

DIN 51900-3 - Testing of solid and liquid fuels e determination of gross calorific value by the bomb calorimeter and calculation of net calorific value e part 3: method using adiabatic jacket, 2005.

FERMOSO, J.; STEVANOV, C.; MOGHTADERI, B.; ARIAS, B.; PEVIDA, C.; PLAZA, M.G.; RUBIERA, F.; PIS, J.J. High-pressure gasification reactivity of biomass chars produced at different temperatures. J. Anal. Appl. Pyrolysis, v. 85, p. 287-293, 2009.

GEORGE, A.; DUGWELL, D.R.; KANDIYOTI, R. Development of a miniaturized technique for measuring the leachability of toxic trace elements from coal-biomass co-combustion ash residues. Energy Fuels, v. 21(2), p. 728-734, 2008.

GUERRERO, M.; RUIZ, M.P.; ALZUETA, M.U.; BILBAO, R.; MILLERA, A. Pyrolysis of eucalyptus at different heating rates: studies of char characterization and oxidative reactivity. J. Anal. Appl. Pyrolysis, v. 74, p. 307$314,2005$.

KUMAR, M.; GUPTA, R.C. Influence of carbonization conditions on the gasification of acacia and eucalyptus wood chars by carbon dioxide. Fuel, v. 73(12), p. 1922-1925, 1994.

LINK, S.; ARVELAKIS, S.; HUPA, M.; YRJAS, P.; KÜLAOTS, I.; PAIST, A. Reactivity of the biomass chars originating from reed, douglas fir, and pine. Energy Fuels, v. 24, p. 6533-6539, 2010.

MANSARAY, K.G.; GHALY, A.E. Determination of kinetic parameters of rice husks in oxygen using thermogravimetric analysis. Biomass and Bioenergy, v. 17, p. 19-31, 1999.

MANSARAY; K.G.; GHALY, A.E.; AL-TAWEEL, A.M.; HAMDULLAHPUR, F.; UGURSAL, V.I. Air gasification of rice husk in a dual distributor type fluidized bed gasifier. Biomass and Bioenergy, v. 17, p. 315-332, 1999.

OLLERO, P.; SERRERA, A.; ARJONA, R., ALCANTARILLA, S. The $\mathrm{CO}_{2}$ gasification kinetics of olive residue. Biomass and Bioenergy, v. 24(2), p. 151-161, 2003.

PINDORIA, R.V.; MEGARITIS, A.; MESSENBÖCK, R.C.; DUGWELL, D.R.; KANDIYOTI, R. Comparison of the pyrolysis and gasification of biomass - effect of reacting gas atmosphere and pressure on Eucalyptus wood. Fuel, v. 77(11), p. 1247-1251, 1998.

RAVEENDRAN, K.; GANESH, A. Adsorption characteristics and pore development of biomass pyrolysis char. Fuel, v. 77, p. 769-781, 1998.

RICHAUD, R.; LACHAS, H., COLlOT, A.G.; MANNERINGS, A.G.; HEROD, A.A.; DUGWELl, D.R.; KANDIYOTI, R. Trace mercury concentrations in coals and coal-derived material determined by atomic absorption spectrophotometry. Fuel, v. 77, p. 359-368, 1998.

RICHAUD, R.; LACHAS, H., HEALEY, A.E.; REED, G.P.; HAINES, J.; MASON, P., HEROD, A.A.; DUGWELL, D.R.; KANDIYOTI, R. Trace element analysis of gasification plant samples by ICP-MS: validation by comparison of results from two laboratories. Fuel, v. 79, p. 1077-1087, 2000.

VENDERBOSCH, R.H.; PRINS, W. Review: Fast pyrolysis technology development. Biofuels, Bioproducts \& Biorefining, v. 4, p. 178-208, 2010.

VIRMOND, E. Utilização de resíduos agroindustriais como fonte alternativa de energia. Tese de Doutorado. Universidade Federal de Santa Catarina, UFSC. Florianópolis, SC, Brasil. 2011. 265 p.

ZOLIN, A.; JENSEN, A.; JENSEN, P.A.; FRANDSEN, F.; DAM-JOHANSEN, K. The influence of inorganic materials on the thermal deactivation of fuel chars. Energy Fuel, v. 15, p. 1110-1122, 2001. 